\title{
Congenital Absence of Posterior Elements of C2 Vertebra with Atlanto-Axial Dislocation and Basilar Invagination: A Case Report and Review of Literature
}

\author{
Sudhir Kumar Srivastava, Pradip Sharad Nemade, Rishi Anil Aggarwal, Sunil Krishna Bhoale \\ Department of Orthopaedics, Seth G.S. Medical College and KEM Hospital, Maharashtra, India
}

\begin{abstract}
Developmental anomalies of the axis are commonly encountered, especially anomalies involving the odontoid process. Anomalies of the posterior elements are uncommon. We describe a unique case of agenesis of posterior elements of $\mathrm{C} 2$ with basilar invagination and atlanto-axial dislocation. An obese 8-year-old boy presented with symptoms of cervical myelopathy. Radiological workup revealed a craniovertebral junction anomaly with occipitalised atlas, absent posterior elements of axis, and hypertrophied C3 spinous process. Atlanto-axial instability and basilar invagination was present. Magnetic resonance angiography revealed hypoplastic left vertebral artery. Traction with cervical tongs failed to improve the alignment and symptoms. Anterior trans-oral release, followed by posterior decompression and custom-made instrumentation, was done. The patient recovered completely and was asymptomatic at the end of two years. X-ray and computed tomography scan demonstrated reduction of basilar invagination and maintenance of alignment. This is the first case to be reported of agenesis of posterior elements of axis associated with basilar invagination. One should look for this condition in patients with hypertrophied spinous process of C3. Utilization of hypoplastic pedicle of axis serves as an additional fixation point to increase the stability of the construct.
\end{abstract}

Keywords: Absent posterior elements of axis; Basilar invagination; Atlanto-axial; Dislocation

\section{Introduction}

Developmental anomalies of the axis are commonly encountered, especially anomalies involving the odontoid process $[1,2]$. These range from anomalies of fusion to complete aplasia [2]. Anomalies of the posterior elements are uncommon. These include invagination of lamina of $\mathrm{C} 2$ and agenesis of the posterior elements of C2 [311]. Patients usually present with progressive myelopathy or, rarely, as mechanical neck pain. We describe a case involving absence of posterior elements of $\mathrm{C} 2$ having occipitalisation of $\mathrm{C} 1$ with mobile atlanto-axial dislocation
(AAD) and basilar invagination. To our knowledge, this is the first case to be reported of agenesis of posterior elements of axis, presenting as cervical myelopathy due to basilar invagination.

\section{Case Report}

An 8-year boy presented to the outpatient department with neck pain, progressive imbalance and difficulty in walking, since 6 months duration. On examination, he was found to be obese, with a body mass index of 31.42 $\mathrm{kg} / \mathrm{m}^{2}$. He had a low hairline and stiffness of neck move-

\footnotetext{
Received Mar 23, 2015; Revised Apr 8, 2015; Accepted Apr 12, 2015

Corresponding author: Rishi Anil Aggarwal

Department of Orthopaedics, Seth G.S. Medical College and KEM Hospital,

Parel, Mumbai-400012, Maharashtra, India

Tel: +91-22-410-7463, Fax: +91-22-2414-3435, E-mail: ris1987@gmail.com
} 
ments. Power and sensations in all extremities were normal; however, he had spasticity and exaggerated deep tendon reflexes in all four extremities. The plantar response was extensor. Static and dynamic radiographs of cervical spine revealed mobile AAD, absent spinous process of axis and hypertrophied C3 spinous process (Fig. 1). Due to occipitalisation of atlas and basilar invagination, the atlanto-dens interval (ADI) was difficult to calculate in dynamic radiographs (ADI could be marked on digitally magnified images). However, the inter-spinous process distance between $\mathrm{C} 1$ and $\mathrm{C} 3$ was more in flexion, and decreased to normal alignment in extension (Fig. 1B, C). Both these parameters demonstrated a mobile ADD. The C5-C6 spinous processes were fused with each other.

The computed tomography (CT) scan of cervical spine with $3 \mathrm{D}$ reconstruction further illustrated the pathoanatomy of the condition (Figs. 2, 3). Occipitalisation of atlas, absent laminae and spinous process of the axis was seen; the pedicles were hypoplastic. On CT scan, the narrowest pedicle diameter was $2.9 \mathrm{~mm}$. The transverse process and the vertebral foramen were well formed. The tip of the odontoid process was proximal to the Mcrae's line, indicating basilar invagination. Magnetic resonance imaging (MRI) scan revealed the compression of medulla and spinal cord till the C3 level (Fig. 4). MR angiography revealed a hypoplastic left vertebral artery. The patient was put on skeletal traction for a week; however, it failed

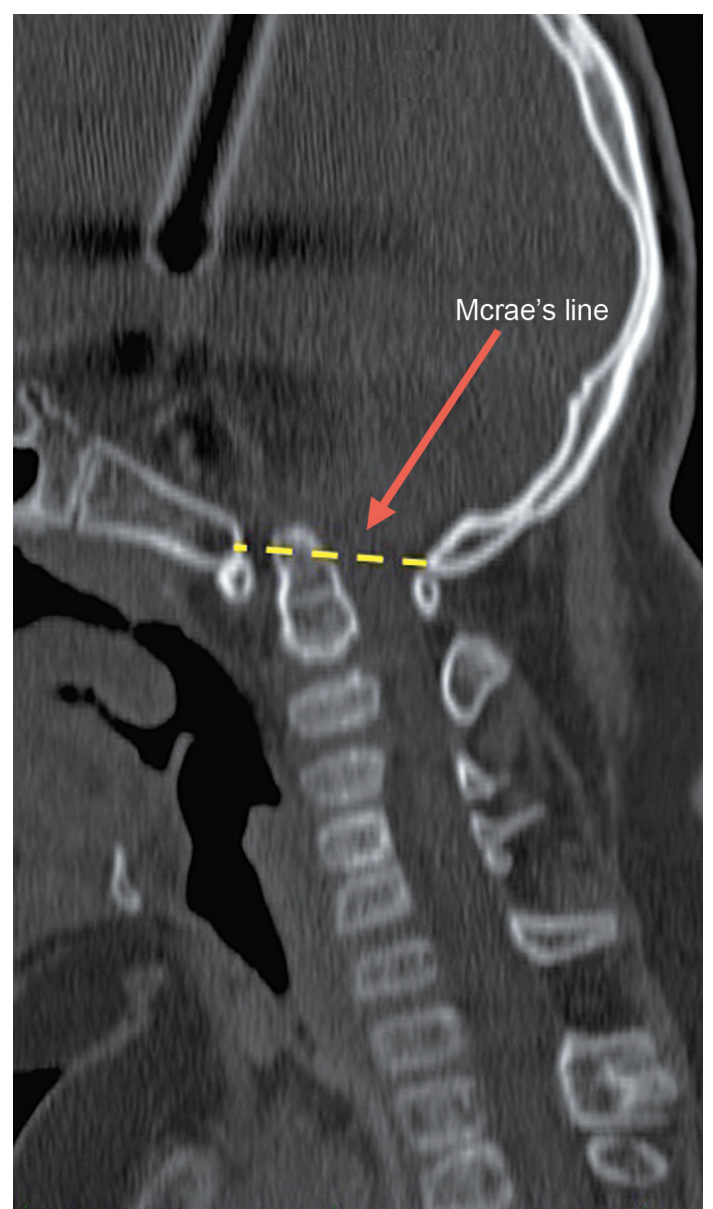

Fig. 2. Computed tomography scan showing tip of odontoid process above the Mcrae's line, suggesting basilar invagination. There is occipitalisation of atlas.
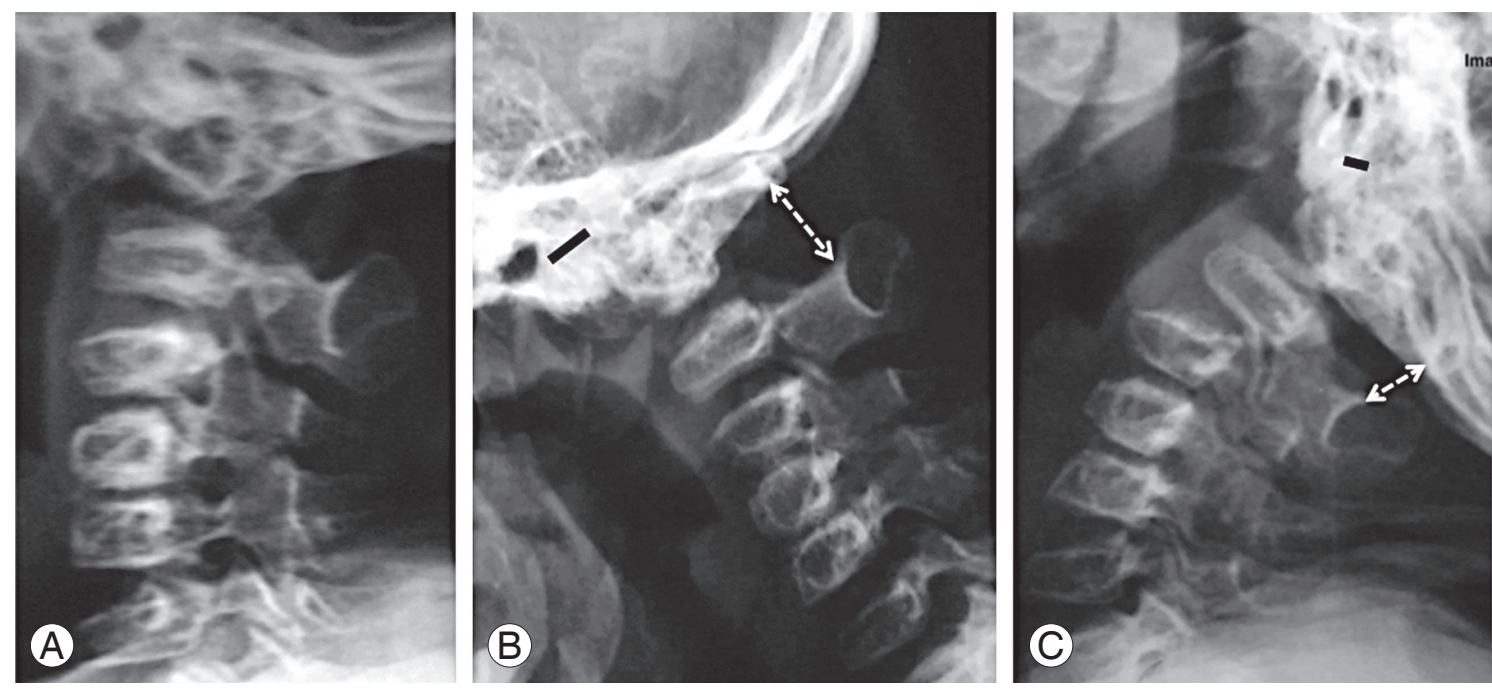

Fig. 1. (A) Lateral X-ray of cervical spine demonstrating absence of posterior elements of C2 vertebra with hypertrophied spinous process of C3. (B, C) Flexion and extension view of cervical spine demonstrating mobile atlanto-axial dislocation. Black line denotes the atlanto-dens interval, which increases in flexion and reduces in extension. White dashed arrows denote the interspinous process distance between $\mathrm{C} 1$ and $\mathrm{C} 3$, which is more in flexion and decreases in extension. Both these parameters indicate a mobile atlanto-axial dislocation. 

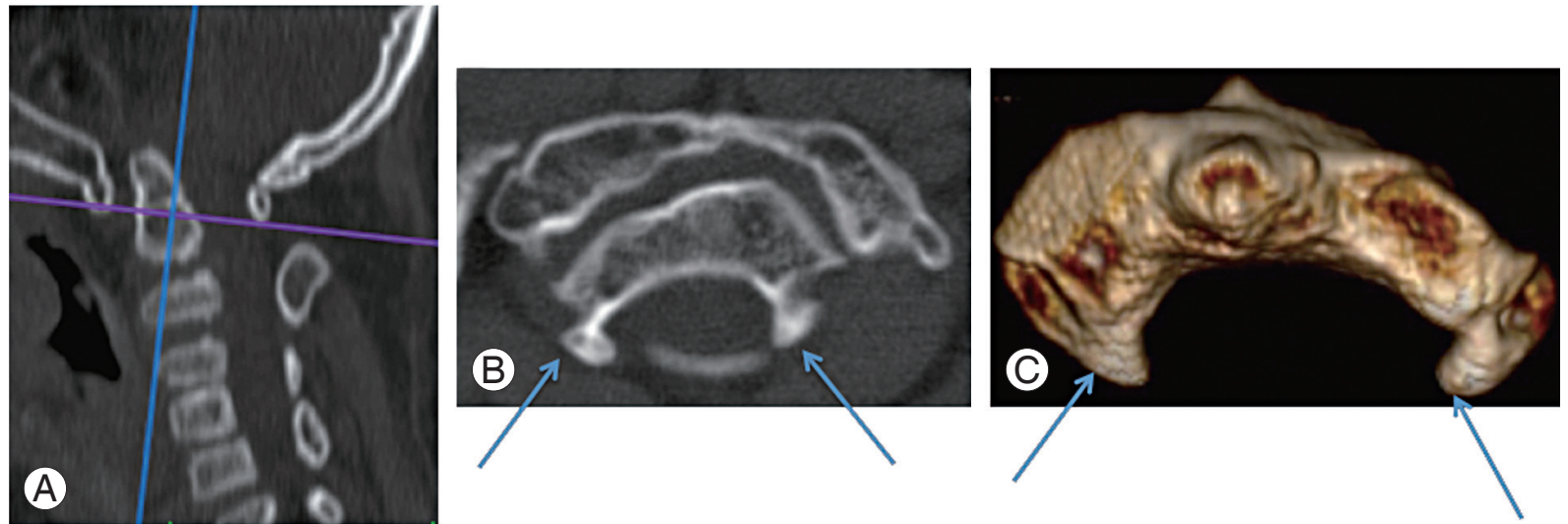

Fig. 3. (A) Reference sagittal section showing the level at which axial cut (B) has been taken. (B) Axial cut showing hypoplastic pedicles of axis with absent lamina and spinous process. (C) Three-dimensional reconstruction of C2 vertebra showing absent spinous process and lamina with hypoplastic pedicles (blue arrows).

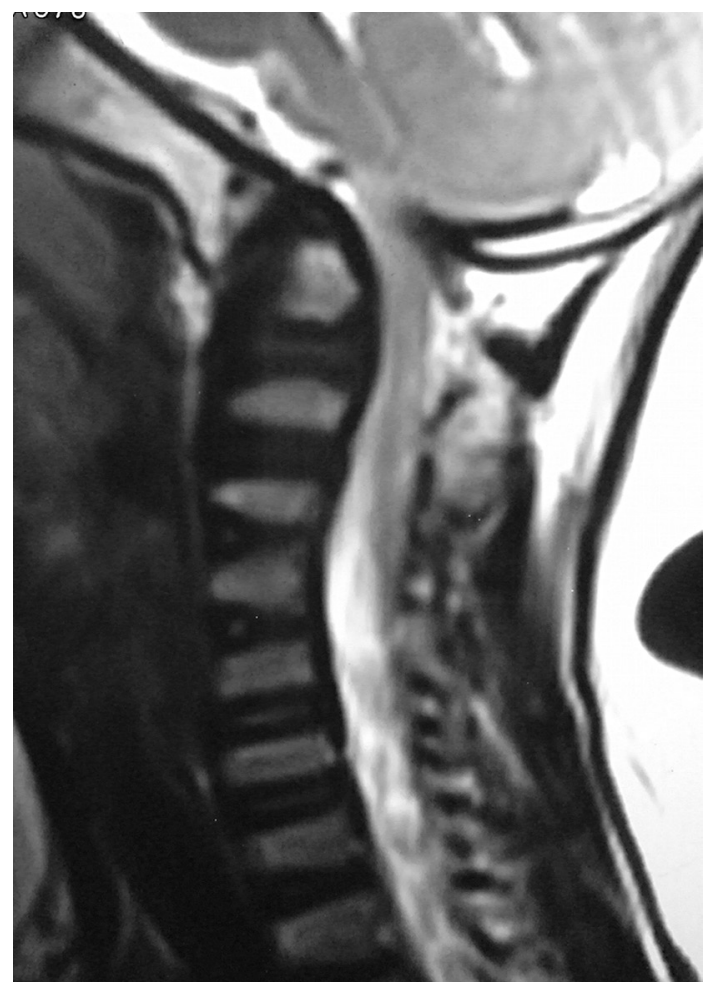

Fig. 4. Magnetic resonance imaging showing compression of medulla and spinal cord till C3 level.

to improve the alignment or symptoms. The patient then underwent an anterior transoral release, followed by posterior instrumented occiput-C4 fusion. The rudimentary $\mathrm{C} 2$ pedicles were utilised as additional fixation points, after manufacturing custom-made $2.7 \mathrm{~mm}$ screws. Thorough cord decompression and posterior iliac crest bone grafting was done between occiput and C3. Prior to grafting, the cancellous bone between the two tables of

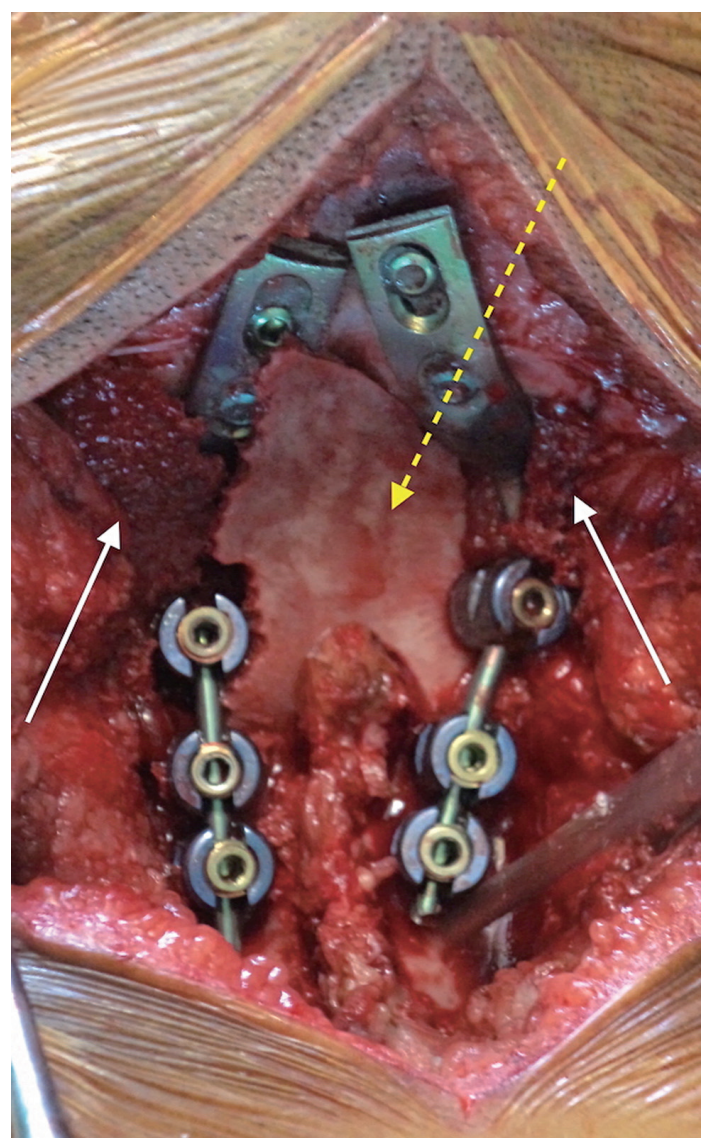

Fig. 5. Intra-operative image showing occiput-C4 instrumentation. A cortico-cancellous bone graft has been placed between occiput and spinous process of C3 (dotted yellow arrow). Additional cancellous bone graft has been placed laterally between C2 and occiput (white arrows).

the occiput was exposed by burring the outer table. An " $H$ " shaped graft was put between C3 and occiput (Fig. 5). Additional cancellous bone graft was put laterally 
between $\mathrm{C} 2$ and occiput to promote fusion. The patient was mobilised on day 14-postoperative, with the help of a sterno-occipto-mandibular immobiliser brace. At the

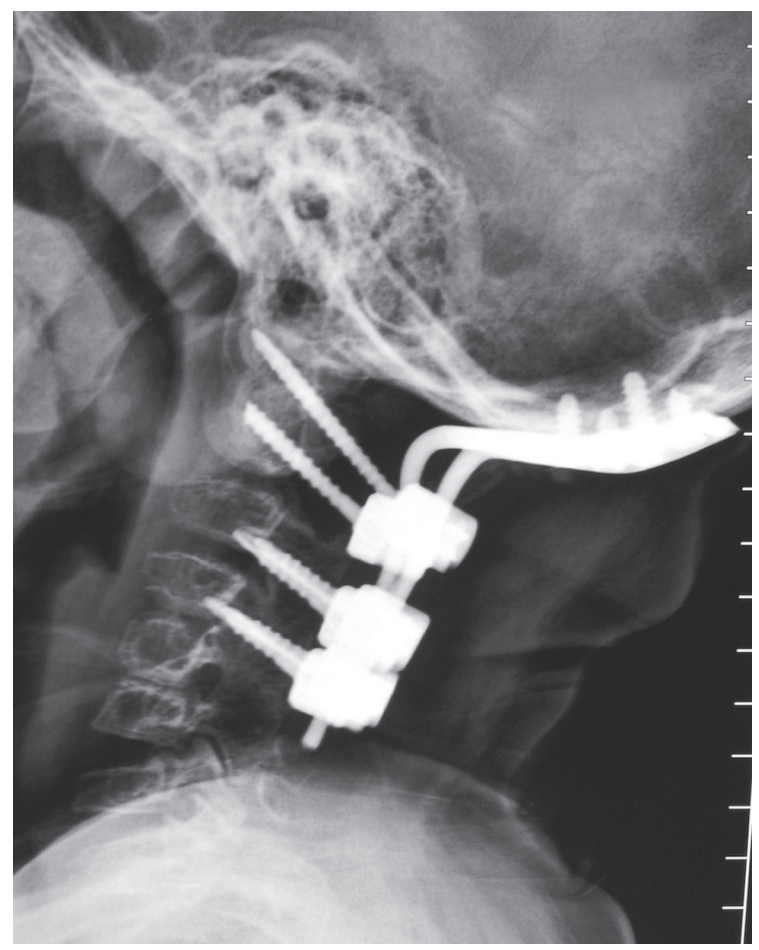

Fig. 6. Follow-up X-ray demonstrating maintenance of alignment.

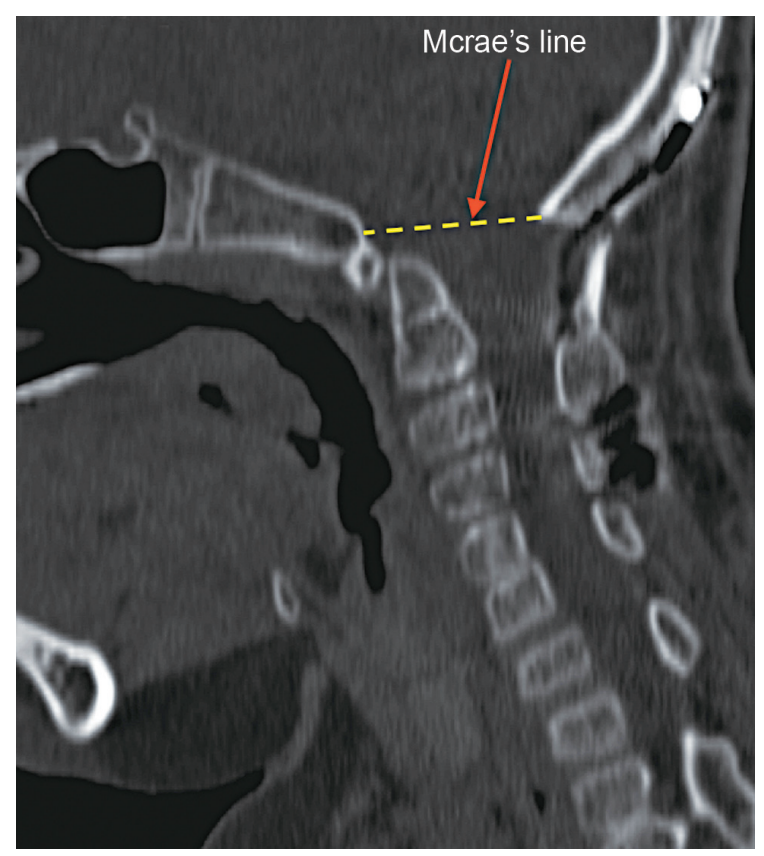

Fig. 7. Follow-up computed tomography scan showing maintenance of reduction of basilar invagination, shown by tip of odontoid process being below the Mcrae's line. end of two years, the patient was asymptomatic; stability and alignment were maintained as confirmed by dynamic radiographs and CT scan (Figs. 6, 7).

\section{Discussion}

Developmental anomalies are common in odontoid process. However, anomalies of posterior elements of axis are uncommon. These include invagination of lamina of axis causing cord compression and absence of posterior elements of axis [3-11]. There are 7 reported cases of absent posterior elements of axis (Table 1). Additionally, Vangilder et al. [9] reported a case of "spina bifida of axis" in 1987; however details of the case are unavailable.

The axis develops from the second spinal sclerotome in three essential stages [12-14]. The stages of development of neural arch of axis and the accompanying defect due to failure of the stage have been summarized in Table 2. The defect in the posterior elements of the axis may be caused by the failure of the extension of the chondrification centers in the posterior arch, or by the failure of the ossification process $[3,15]$. In our patient, the absence of the cartilaginous remnant of posterior elements of axis indicated the failure of dorsal migration of cells from the second spinal sclerotome, or failure of chondrification leading to failure of formation of the neural arch.

Most of the cases reported till date had varying degrees of anterolisthesis of C2 over C3 [7,10,11]. However, the causal relationship of absent posterior elements to the anterolisthesis has not yet been postulated. We believe that hypoplasia or aplasia of the posterior elements could have compromised the structural integrity of $\mathrm{C} 2-\mathrm{C} 3$ facet joints, leading to instability and subsequent anterolisthesis. The present case, however, is unique because of the presence of basilar invagination. Occipitalisation of atlas and multiple fused vertebrae could have concentrated the flexion extension force on $\mathrm{C} 1-\mathrm{C} 2$ leading to $\mathrm{AAD}$. The hypertrophied spinous process of $\mathrm{C} 3$ represents a compensatory mechanism to provide attachment to interspinous ligament and paraspinal muscles, otherwise attached to spinous process of axis.

Being a congenital anomaly, we included MR angiography in the preoperative workup. Angiography revealed hypoplastic left vertebral artery. This had important clinical implications, as we had to be extra cautious while inserting the right-sided screws.

Our patient had a basilar invagination, which was ir- 
Table 1. Table showing cases reported of absence of posterior elements of C2

\begin{tabular}{|c|c|c|c|c|c|}
\hline Year & Author & $\begin{array}{l}\text { Age }(y r) / \\
\text { sex }\end{array}$ & Presentation & Radiological findings & Management \\
\hline 1987 & Morizono et al. [8] & 20/male & $\begin{array}{l}\text { Neck pain } \\
\text { Headache }\end{array}$ & $\begin{array}{l}\text { Absent spinous process and arch of } \mathrm{C} 2 \text {; } \\
\text { hypertrophied spinous process of } \mathrm{C} 3 \text {; } \\
\mathrm{C} 2 / 3 \text { anterolisthesis of } 2 \mathrm{~mm} \text { on flexion }\end{array}$ & Traction \\
\hline 1987 & Vangilder et al. [9] & NA & NA & Spina Bifida of axis & NA \\
\hline 1999 & Goel et al. [7] & 42/male & $\begin{array}{l}\text { Progressive } \\
\text { myelopathy }\end{array}$ & $\begin{array}{l}\text { Absence of posterior axis; dislocation of } \\
\text { C2 over C3 }\end{array}$ & $\begin{array}{l}\text { Posterior fixation } \rightarrow \text { transoral } \\
\text { C } 2 / 3 \text { decompression }\end{array}$ \\
\hline 1999 & Goel et al. [7] & 16/male & $\begin{array}{l}\text { Progressive } \\
\text { myelopathy }\end{array}$ & $\begin{array}{l}\text { Absence of posterior axis; dislocation of } \\
\text { C2 over C3 }\end{array}$ & $\begin{array}{l}\text { Anterior decompression+posterior } \\
\text { fusion }\end{array}$ \\
\hline 2003 & Trivedi et al. [10] & 31/female & $\begin{array}{l}\text { Neck pain and } \\
\text { stiffness }\end{array}$ & $\begin{array}{l}\text { Absence of posterior axis; anterolisthesis } \\
\text { of C2 over C3 }\end{array}$ & $\begin{array}{l}\text { Posterior 0-C3 fixation and fusion } \\
\text { without decompression }\end{array}$ \\
\hline 2004 & Behari et al. [6] & 12/male & $\begin{array}{l}\text { Progressive } \\
\text { quadriparesis }\end{array}$ & $\begin{array}{l}\text { Fixed } A A D \text {; Occipitalised } \mathrm{C} 1 \text {; absence of } \\
\text { spinous process and lamina of } \mathrm{C} 2\end{array}$ & $\begin{array}{l}\text { Transoral decompression+posterior } \\
\text { OC fixation and fusion }\end{array}$ \\
\hline 2004 & Behari et al. [6] & 16/male & $\begin{array}{l}\text { Progressive } \\
\text { quadriparesis }\end{array}$ & $\begin{array}{l}\text { Mobile AAD; normal C1; absent C2 } \\
\text { lamina; "free floating" spinous process } \\
\text { C2 }\end{array}$ & $\begin{array}{l}\text { Posterior decompression+0-C4 } \\
\text { fixation and fusion }\end{array}$ \\
\hline 2004 & $\begin{array}{l}\text { Muzumdar and } \\
\text { Goel [11] }\end{array}$ & 31/male & $\begin{array}{l}\text { Progressive } \\
\text { quadriparesis }\end{array}$ & $\begin{array}{l}\text { Absence of posterior axis; dislocation of } \\
\text { C2 over C3 }\end{array}$ & $\begin{array}{l}\text { Transoral decompression+anterior } \\
\text { fixation }\end{array}$ \\
\hline 2014 & Current case & 8/male & $\begin{array}{l}\text { Progressive } \\
\text { myelopathy }\end{array}$ & $\begin{array}{l}\text { Absent lamina and spinous process of } \\
\mathrm{C} 2 \text {; rudimentary pedicles of } \mathrm{C} 2 \text {; basilar } \\
\text { invagination; occipitalised } \mathrm{C} \text {; mobile } \\
\text { AAD hypertrophied spinous process of } \mathrm{C} 3\end{array}$ & $\begin{array}{l}\text { Transoral release followed by } \\
\text { posterior decompression and } \\
\text { 0-C4 fixation and fusion }\end{array}$ \\
\hline
\end{tabular}

Cases have been listed in chronological order of date of publication.

NA, not available; AAD, atlanto-axial dislocation; 0-C4, occiput to C4.

Table 2. Table showing stages in development of neural arch of C2 vertebra and accompanying defect in case of failure of the particular stage

\begin{tabular}{|c|c|c|c|}
\hline Stage & Timing & Process & Defect due to failure of stage \\
\hline Pre-cartilage & $\begin{array}{l}\text { Begins at fourth week and } \\
\text { ends at eighth week }\end{array}$ & $\begin{array}{l}\text { Cells of the sclerotome migrate ventromedially } \\
\text { to surround the notochord forming the centrum } \\
\text { that forms the body. At the eighth post-ovulatory } \\
\text { week, the cells extend ventrolaterally to form the } \\
\text { transverse process and foramen transversarium } \\
\text { [16], and dorsally to form the neural arch from } \\
\text { which the pedicles, articular processes and } \\
\text { lamina develop. }\end{array}$ & $\begin{array}{l}\text { Absence of even cartilaginous } \\
\text { framework of different parts } \\
\text { of vertebrae. }\end{array}$ \\
\hline Chondrification & $\begin{array}{l}\text { Begins at sixth week and } \\
\text { ends at fourth month }\end{array}$ & Begins at the pedicle and ends in the midline & $\begin{array}{l}\text { Absence of even cartilaginous } \\
\text { framework. }\end{array}$ \\
\hline Ossification & Begins at eighth week & $\begin{array}{l}\text { Body-arch fusion: } 4-6 \text { years } \\
\text { Fusion between two pieces of arch: } 5-8 \text { years }\end{array}$ & $\begin{array}{l}\text { Cartilaginous framework present } \\
\text { but no bone formation. }\end{array}$ \\
\hline
\end{tabular}

reducible on cervical traction. Thus, we opted for anterior transoral release of contracted structures, as described by Wang et al. [16]. After confirming reduction of basilar invagination on fluoroscopy, we did posterior O-C4 fixation and fusion in the same setting. Hypoplastic pedicles of $\mathrm{C} 2$ were utilized as extra fixation points. Hypoplastic pedicles were exposed and cortical bone overlying the pedicle was burred. Entry was made using a pedicle finder and a ball tip probe was used to palpate the tract of pedicle screw. Check X-ray was taken to confirm the trajectory and placement. Since the diameter was small, $2.7 \mathrm{~mm}$ polyaxial screws were passed in the pedicles of C2. The diameter was decided preoperatively, after careful measurement on CT scan. This increased the strength of the construct and 
aided in maintenance of reduction.

Almost all cases of agenesis of posterior elements of C2 have presented with myelopathy, and no asymptomatic cases have been reported in literature [6-11]. Thus, it is prudent to believe that a patient with missing posterior elements of C2 may/will develop symptoms some time in their lifetime. One must closely follow-up such patients and consider performing instrumented fusion if patient develops even early clinical evidence of myelopathy, because once myelopathy becomes severe, the chances of complete neurological recovery are poor.

We present a unique case of absent posterior elements of axis with occipitalised $\mathrm{C} 1$, mobile AAD and basilar invagination, presenting as cervical myelopathy. Absent posterior elements of axis is a rare condition. One should look for this condition in patients with hypertrophied spinous process of C3. Close follow up is necessary, and fusion may be considered in patients who develop myelopathy. Careful preoperative evaluation should be done. Angiography must be considered to identify anomalies in vertebral artery. Utilization of hypoplastic pedicle of axis serves as additional fixation point to increase the stability of construct. Further experience is mandatory to formulate an appropriate treatment protocol for this complex anomaly.

\section{Conflict of Interest}

No potential conflict of interest relevant to this article was reported.

\section{References}

1. Hosalkar HS, Sankar WN, Wills BP, Goebel J, Dormans JP, Drummond DS. Congenital osseous anomalies of the upper cervical spine. J Bone Joint Surg Am 2008;90:337-48.

2. Guille JT, Sherk HH. Congenital osseous anomalies of the upper and lower cervical spine in children. J Bone Joint Surg Am 2002;84:277-88.

3. Asakawa H, Yanaka K, Narushima K, Meguro K, Nose T. Anomaly of the axis causing cervical myelopathy: case report. J Neurosurg 1999;91:121-3.

4. Chau AM, Wong JH, Mobbs RJ. Cervical myelopathy associated with congenital $\mathrm{C} 2 / 3$ canal stenosis and deficiencies of the posterior arch of the atlas and laminae of the axis: case report and review of the lit- erature. Spine (Phila Pa 1976) 2009;34:E886-91.

5. Jiang Y, Xi Y, Ye X, Xu G, He H, Zhu Y. A cervical myelopathy caused by invaginated anomaly of laminae of the axis in spina bifida occulta with hypoplasia of the atlas: case report. Spine (Phila Pa 1976) 2010; 35:E351-5.

6. Behari S, Kiran Kumar MV, Banerji D, Chhabra DK, Jain VK. Atlantoaxial dislocation associated with the maldevelopment of the posterior neural arch of axis causing compressive myelopathy. Neurol India 2004;52:489-91.

7. Goel A, Gupta S, Laheri V. Congenital absence of posterior elements of axis: a report of two cases. Br J Neurosurg 1999;13:459-61.

8. Morizono Y, Sakou T, Maehara T. Congenital defect of posterior elements of the axis. Clin Orthop Relat Res 1987;(216):120-3.

9. Vangilder JC, Menezes AH, Dolan KD. Radiology of asymptomatic craniovertebral anomalies and abnormalities. In: VanGilder JC, Menezes AH, Dolan KD, editors. The craniovertebral junction and its abnormalities. Mount Kisco, N.Y.: Futura Pub. Co.; 1987. p.69-98.

10. Trivedi P, Vyas KH, Behari S. Congenital absence of the posterior elements of C2 vertebra: a case report. Neurol India 2003;51:250-1.

11. Muzumdar DP, Goel A. C2 over C3 spondyloptosis in a case with absent posterior elements: report of an unusual case and analysis of treatment options. J Clin Neurosci 2004;11:675-7.

12. Pang D, Thompson DN. Embryology and bony malformations of the craniovertebral junction. Childs Nerv Syst 2011;27:523-64.

13. Kaplan KM, Spivak JM, Bendo JA. Embryology of the spine and associated congenital abnormalities. Spine J 2005;5:564-76.

14. O'Rahilly R, Muller F, Meyer DB. The human vertebral column at the end of the embryonic period proper. 2. The occipitocervical region. J Anat 1983; 136:181-95.

15. Vangilder JC, Menezes AH. Craniovertebral junction abnormalities. Clin Neurosurg 1983;30:514-30.

16. Wang C, Yan M, Zhou HT, Wang SL, Dang GT. Open reduction of irreducible atlantoaxial dislocation by transoral anterior atlantoaxial release and posterior internal fixation. Spine (Phila Pa 1976) 2006;31:E30613. 